удк 338.462

DOI https://doi.org/10.32851/2708-0366/2020.4.11

Кацемір Я.В.

кандидат економічних наук,

Херсонський державний аграрно-економічний університет ORCID: https://orcid.org/0000-0003-2919-4032

Katsemir Yana

Kherson State Agrarian and Economic University

\title{
НАПРЯМИ ПІДВИЩЕННЯ КОРИСНОСТІ ПОСЛУГ У тУРИстИЧномУ ПРОДУКТІ
}

\section{DIRECTIONS OF INCREASING THE USEFULNESS OF SERVICES IN A TOURIST PRODUCT}

\begin{abstract}
Розвиток сучасного туризму багато в чому залежить від розроблення та впровадження інновачійних технологій, спрямованих на вдосконалення обслуговування клієнтів і розщирення сервісних туристичних можливостей. Нині ми можемо спостерігати сильну конкуренцію, виходять на ринок нові туристичні иееттри, блискавично розвиваються інтернет-технології та онлайн-продажі, споживачі все частіше бажають поєднати різні види відпочинку, а також спостерігається скорочення тривалості туристських поӥздок. Все ие змушує замислюватися й постійно перебувати в пошуку нових способів просування туристських продуктів, оскільки успішна робота туристичної фірми залежсть не тільки від потрібного продукту високої якості, орієнтованого на ринок иінової політики, але й від систематичного та ефективного зв'язку з потениійним клієнтом і торговими посередниками. У статті представлено відомості щзодо очінювання й підвищення корисності послуг у комплексному туристичному продукті та їх грамотному застосуванні на підприємствах изіє̈̈ галузі.
\end{abstract}

Ключові слова: туризм, туристичний продукт, корисність послуг, привабливість продукту, споживачі послуг.

Развитие современного туризма во многом зависит от разработки и внедрения инновационных технологий, направленных на совершенствование обслуживания клиентов и расширение сервисных туристических возможностей. Сейчас мы можем наблюдать сильную конкуренцию, выходят на рынок новые туристические иентры, молниеносно развиваются интернет-технологии и онлайн-продажи, потребители все чаще желают совместить разные виды отдыха, а также наблюдается сокрашуение продолжстельности туристских поездок. Все это заставляет задумываться и постоянно находиться в поиске новых способов продвижения туристских продуктов, поскольку успешная работа туристической фирмы зависит не только от нужного продукта высокого качества, ориентированного на рынок иееновой политики, но и от систематической и эффективной связи с потенциальным клиентом и торговыми посредниками. В статье представлены сведения по очениванию и повышению полезности услуг в комплексном туристическом продукте $u$ их грамотном применении на предприятиях этой отрасли.

Ключевые слова: туризм, туристический продукт, полезность услуг, привлекательность продукта, потребители услуг.

Modern challenges of the "consumer society" create many dilemmas for young people in determining their own directions and goals of life, aspirations and forecasting any personal and professional results, in understanding the true enduring values and socio-economic indicators for society as a whole and for an individual. The development of modern tourism largely depends on the development and implementation of innovative technologies aimed at improving customer service and expanding service tourism opportunities. Currently, we can observe strong competition, new tourist centers are entering the market, Internet technologies and online sales are developing at lightning speed, consumers increasingly prefer to combine different types of recreation, and there is also a decrease in the duration of tourist trips. All this makes us think and constantly look for new ways to promote tourism products, since the successful work of a travel 
company depends not only on the desired high quality product, market-oriented pricing policy. Systematic and effective communication with potential clients and resellers is also required. Tourist activity can be viewed as the activity of tour operators and travel agents in the formation of a product, namely, a tourist product, on the one hand, and the actions of tourists consuming a tourist product, on the other. The tourist product is the basis of the tourist offer and tour. A tourist product as a commodity is characterized by consumer value, that is, by its utility or ability to satisfy certain needs of people for leisure and recreation. Utility a tourist product is determined by its value for the consumer. Because of this, tour operators strive to create such a tourism product, which would be valuable for the largest possible number of people, i.e., if possible, it should have a mass consumer. At the moment, there is a tendency in the tourism market to populate an individual approach and form more a narrowly targeted tourist product, which may include a tourist and excursion program, food, guide services, alcohol, creating a photo report from a trip, etc. The article presents information on the assessment and improvement of the usefulness of services in a complex tourist product and their competent application at the enterprises of this industry.

Key words: tourism, tourist product, usefulness of services, product attractiveness, consumers of services.

Постановка проблеми. Управління привабливістю туристичного продукту грунтується на системному підході до управління, дає змогу домогтися постійного вдосконалення надання туристичних послуг, забезпечувати високий рівень підготовки співробітників туристського підприємства, більш ефективно використовувати наявний у нього матеріально-технічний, кадровий, інформаційний та фінансовий потенціал. Туристський продукт як товар характеризується споживчою вартістю, тобто корисністю або здатністю задовольняти певні потреби людей у дозвіллі та відпочинку. Корисність туристичного продукту визначається його цінністю для споживача. Через це туроператори прагнуть до створення такого туристичного продукту, який був би цінним для максимально великої кількості людей, тобто за можливості він повинен мати масового споживача.

Аналіз останніх досліджень і публікацій. Значним внеском у дослідження теоретичних і практичних проблем корисності послуг у туристичній сфері стали праці таких науковців, як С.Д. Ільєнкова, В.І. Карсекін, В.С. Качанов, В.О. Квартальнов, В.Ф. Кифяк, О.І. Кочерга, М.П. Мальська, П.Р. Пуцентейло, Х.Й. Роглєва, Г.Г. Савіна, І.О. Сидоренко. Питанням оцінювання якості та ефективності управління системами різного рівня присвячено низку робіт таких учених, як В.А. Дресвянніков, Ю.Т. Шестопал, В.Д. Дорофєєв, Н.Ю. Щетиніна, А.М. Шмельова, Р.Р. Тіміргалєєва, І.Ю. Грішин, С.Ф. Поважний, Р.Р. Ларіна, А.В. Білоусов. Так, у роботі Р.Р. Тіміргалєєва викладено теоретичні аспекти інформаційно-логістичного забезпечення процесу управління складними організаційно-економічними системами, надано системне уявлення про об'єкти управління; у статті I.Ю. Грішина розкриваються проблеми формування оптимального асортименту туристично-рекреаційних послуг; М.А. Шостак включає науково-теоретичні основи управління соціально-економічними системами, питання концептуалізації розвитку підприємств туристично-рекреаційної сфери на основі внутрішнього маркетингу.

Формулювання цілей статті. Метою роботи є дослідження теоретичних та практичних проблем корисності послуг у туристичному продукті, факторів, що впливають на створення якісного туристичного продукту, визначення умов, за яких можливою $\epsilon$ ефективна виробнича діяльність туристичних підприємств.

Виклад основного матеріалу. Туризм належить до сфери діяльності, яка є однією 3 найбільш швидко розвинених і перспективних сфер економіки. Ця діяльність простягається від готелів і транспорту до фінансування й посередництва. У методичному аспекті дуже важливо розмежовувати поняття туристичного продукту та туристичних послуг.

Туристський продукт - це товар у вигляді визначеного набору туристських послуг, що володіють корисністю. Туристичним продуктом у широкому розумінні цього слова може виступати будь-який вид туристичних послуг. 
Туристичні послуги - це виробнича діяльність підприємств туристичної індустрії, яка задовольняє потреби клієнтів і не має, як правило, матеріально-речової форми [5, c. 59].

Важлива відмінність між туристичним продуктом і туристської послугою полягає в тому, що туристична послуга може бути використана тільки в місці її створення, а туристський продукт може бути придбаний і за місцем проживання, але використаний тільки в місці створення туристських послуг. Іншими словами, купуючи туристську путівку, споживач купує товар, а не туристичні послуги. Інакше кажучи, заплативши гроші, він набуває лише можливість отримання певних послуг. Ринок послуг не схожий на ринок товарів $з$ таких причин:

1. Послуга не існує до моменту іiі надання. Це робить складним процесом оцінювання й порівняння послуг, поки вони не надані. Порівнювати між собою можна тільки очікувану й отриману користь;

2. Послугам властивий значний ступінь невизначеності виконання на момент укладення договору про надання послуг, що часто ставить клієнта в скрутне становище, а реалізаторам послуг заважає просувати послуги на ринку.

Всі ці моменти, що стосуються ринку послуг, а також специфічна для послуг нематеріальність, мінливість якості та збіг процесу виробництва й споживання послуг визначають особливості їх надання.

Як і будь-який товар, туристичний продукт має споживчі властивості. Зазвичай у теоретичних розробках, присвячених цьому питанню, виділяються такі основні споживчі якості послуг:

- обгрунтованість (надані послуги мають бути співвіднесені задля подорожі, відповідати потребам туриста і не бути надмірними);

- ефективність (досягнення найкращого результату за розумних витрат із боку туриста);

- надійність (відповідність очікуваного змісту туристичного продукту фактичному, достовірність рекламної інформації);

- цілісність (здатність продукту в повному обсязі задовольняти потреби туриста);

- зрозумілість (умови використання продукту мають бути зрозумілими як туристу, так і персоналу, зайнятому його обслуговуванням);

- простота (мається на увазі простота в експлуатації, що передбачає мінімізацію витрат під час підтримки місць перебування в гідному стані);

- гнучкість (легкість пристосування продукту в системі обслуговування до іншого типу споживача);

- корисність (здатність продукту бути використаним для досягнення як однієї певної, так і комбінованих цілей).

Однак у такому визначенні споживчих властивостей туристичного продукту має місце відсутність розмежування між корисністю продукту для туриста та його корисністю для виробника послуг. Наприклад, простота в експлуатації і гнучкість належать до властивостей туроператора, а не туриста. Отже, надаємо своє визначення споживчих властивостей туристичного продукту, наголошуючи на тому, що належить до виробника послуг, і тому, що належить до туриста, споживача туристичного продукту. Для туриста важливі такі властивості туристичного продукту: ступінь доступу до туристичних ресурсів, що визначається видом туру; рівень фізичного навантаження й «культурного шоку»; вартість і безпека. До властивостей туристичного продукту, що належать до функцій виробника, на нашу думку, належать такі: комфортність (необхідний набір послуг і діапазон рівня навантажень, допустимих для запропонованого туру), надійність (відповідність змісту туру рекламі), економічність (мінімізація витрат туриста), конкурентоспроможність (порівнянність за параметрами з аналогічним зарубіжним туром), гнучкість (легкість пристосування продукту в системі обслуговування до іншого типу споживача). 
Залежно від виду туризму та групи туриста до кожного туру висуваються конкретні вимоги до послуг, які входять у туристичний продукт. 3 цього можна зробити висновок, що у кожної послуги з огляду на її корисність є свої пріоритетності та вагомості. Пріоритетна та вагома послуга для одного суб'єкта може бути абсолютно нецікавою для іншого. Це стосується як прямих, так і опосередкованих послуг.

Пріоритет - це переважне, головне значення чого-небудь, те, що вважається найбільш важливим, вимагає до себе першочергової уваги. Пріоритетність - це першість, важливість деякого параметра.

Пріоритетність послуг для споживача проявляється через визначення споживачем ступеня значущості тієї чи іншої послуги порівняно з іншими послугами.

Вагомість - це відчутність, значність, принципове значення, престижність, цінність, важливість того чи іншого параметра. В економічному сенсі вагомість послуги треба розглядати окремо $з$ точки зору споживача та окремо з точки зору виробника послуг. 3 точки зору споживача вагомість послуги - це міра, яка відображає вимоги споживачів, їх задоволеність послугами. 3 точки зору виробника послуг вагомість - це міра реалізації економічних та соціальних інтересів підприємства. Принципова різниця між пріоритетністю та вагомістю послуг полягає в такому: розрив у послідовних пріоритетах завжди $є$ постійною величиною і не може бути покладений в основу визначення реальних зусиль, необхідних для підвищення привабливості послуги або рівня реалізації послуги за допомогою соціальних та економічних інтересів підприємства.

Зростання таких показників, як корисність та вагомість послуг, які є важливими характеристиками туристичного продукту, приводить до підвищення задоволення потреб споживачів та забезпечення споживчої привабливості туристичного продукту.

Туристичні підприємства під час обслуговування туристів постійно розширюють набір прямих та опосередкованих послуг, що сприяє підвищенню привабливості туристичного продукту загалом.

Іншими словами, високий рівень привабливості туристичного продукту може забезпечити комплексна послуга, яка формується за рахунок послуг прямого та опосередкованого характеру.

Привабливість туристичного продукту формується за рахунок підвищення корисності комплексу прямих та опосередкованих послуг, тобто за рахунок задоволеності туриста від отримання кожної послуги.

Схематично процес оцінювання привабливості туристичного продукту представлено на рис. 1.

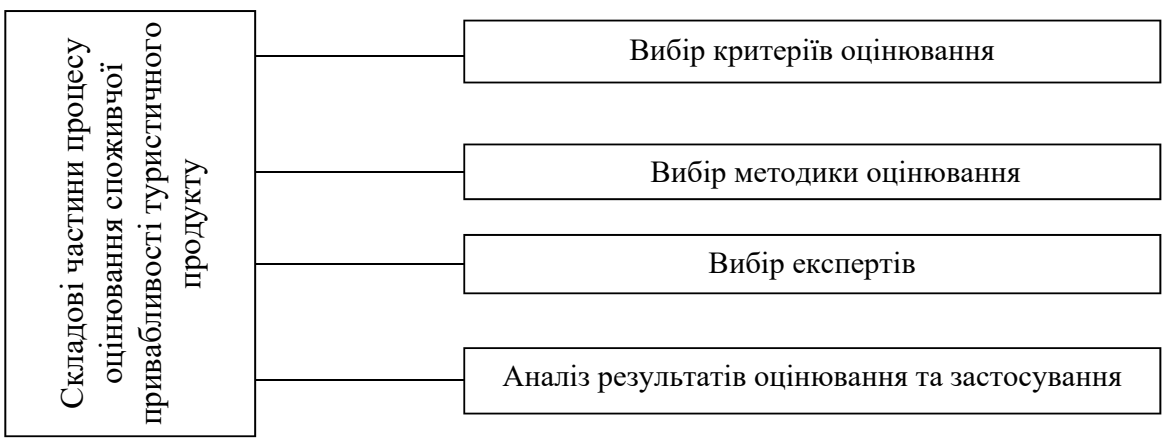

Рис. 1. Схема оичінювання привабливості туристичного продукту

3 великої кількості наявних методів найбільш перспективним для вирішення завдання методичної інструменталізації процесу формування споживчої привабливості туристичних продуктів $є$ метод розрахунку Свропейського індексу задоволено- 
сті споживача (ESCI), на основі якого проводяться системні дослідження рівня задоволеності споживачів у країнах СС [6].

Проаналізувавши за методикою розрахунку ESCI задоволеність споживача, пропонуємо удосконалений процес оцінювання привабливості туристичного продукту.

I етап: визначення переліку прямих та опосередкованих послуг, які впливають на привабливість туристичного продукту.

II етап: визначення вагомості складових частин туристичного продукту.

III етап: оцінювання корисності туристичного продукту за всіма складовими частинами.

IV етап: оцінювання привабливості туристичного продукту з урахуванням вагомості й корисності всіх складових частин.

Методика розрахунку ESCI задоволеності споживача здійснюється у форматі інтерв'ювання споживачів та дає змогу з'ясувати значення й співвідношення якості, ціни та інших перемінних, які можуть бути використані для формування груп постійних та лояльних споживачів.

Досі не розроблена загальноприйнята комплексна системна оцінка корисності послуг в туристичній індустрії, яка б включала всі аспекти: від оцінки реакції споживачів за допомогою анкетування до організації системи статистичного обліку й аналізу параметрів оцінки. Наявні методики оцінки корисності в туризмі зачіпають або якісні, або кількісні параметри.

Однак слід зазначити, що ефективність управління корисністю залежить від оцінки та вимірювання рівня якості.

Під рівнем якості продукту (послуги) розуміється відносна оцінка якості, заснована на порівнянні сукупності показників розглянутого продукту (послуги) з базовими, тобто продуктами (послугами) конкурентів, перспективними зразками, стандартами, випереджальними стандартами.

Розрахунок показників, що оцінюють рівень корисності продукту (послуги), проводиться 3 певною метою, найважливішою серед яких $є$ зіставлення різних споживчих властивостей продукту (послуги) та їх економічних характеристик, тобто визначення оптимального рівня корисності продукту. Зі зростанням вимог, що висуваються споживачами до корисності продукту (послуги), обов'язково зростають його собівартість і ціна.

Оцінка корисності являє собою сукупність операцій, що включають систему показників якості, визначення їх чисельних значень, а також значень базових і відносних показників задля обгрунтування найкращих рішень, реалізованих під час управління корисністю продукту (послуги). Таким чином, алгоритм оцінювання корисності на туристичному підприємстві буде складатися з таких операцій:

- вибір системи показників якості;

- вимірювання, тобто зіставлення з відомими величинами деякої шкали та отримання чисельних значень;

- оцінювання отриманих результатів.

У туристичному бізнесі відбувається вжиття маркетингових заходів, орієнтованих на клієнта, що є безпосереднім споживачем послуг ринку туристичної індустрії, націлених на підвищення лояльності клієнта. Такі заходи доцільно розділити на ті, які збільшують корисність туристичної послуги для певних груп споживачів послуг туристичного бізнесу в результаті надання їм економічних переваг (лояльність, рухома вартістю), і ті, які завдяки формальній та неформальній комунікації, а також взаємодії між постачальником і споживачем підсилюють інтенсивність контактів, підвищують довіру й стабілізують задоволеність послугами організації (лояльність, рухома контактами).

Реалізована клієнтом готелю корисність конкретної послуги на ринку туристичної індустрії визначається, з одного боку, очікуваною та отриманою якістю, а з іншого боку, затребуваною за цю послугу ціною. Відповідно, заходи щодо підвищення лояльності споживачів туристичних послуг в цьому разі можуть бути зорієнтовані на якість або ціну. 
В рамках заходів, орієнтованих на якість послуги, йдеться про те, щоби запропонувати клієнту єдину у своєму роді вигоду, яка може бути заміщена послугою інших постачальників (наприклад, зміна готелю як місця проживання) тільки за більш високих витрат споживача (економічна лояльність). Такої унікальної пропозиції можна досягти шляхом забезпечення поставок послуг за індивідуальним замовленням, зі спеціальним дизайном, на замовлення для задоволення ключових потреб клієнта.

На підвищення економічних бар'єрів під час наміру споживача послуг змінити постачальника (наприклад, готель) націлені цінові заходи, які прямо або у прихованому вигляді пропонують споживачеві матеріальні вигоди в разі повторної покупки послуги. Варіанти заходів цінової мотивації лояльності споживача послуги включають такі елементи:

1) цінові системи, що надають клієнтові переваги в ціні в разі повторної закупівлі порівняно з одноразовою (на це спрямовані різноманітні заохочувальні програми для постійних клієнтів);

2) «пакет цін», який передбачає знижку для певних груп споживачів (наприклад, для ділових туристів, які приїжджають за програмою інсентив-турів);

3) цінові гарантії і договори, що регулюють ціни на певний час (наприклад, знижки вихідного дня на проживання в готелі; встановлення знижок на обід у певні («непікові») години в ресторані («хеппі ауер»)).

Висновки. Управління корисністю послуг у туристичному продукті являє собою погоджену робочу структуру, що функціонує на туристичному підприємстві, а також має включати ефективні технічні й управлінські методи, що забезпечують найкращі і найбільш практичні способи взаємодії персоналу туристичного підприємства, його агентів, контрагентів та споживачів туристичних послуг.

Таким чином, здатність туристичних підприємств досягати своїх цілей із забезпеченням конкурентоспроможності послуг визначається діючою системою організації та управління, а саме системою управління якістю.

\section{Список використаних джерел:}

1. Баумгартен Л.В. Управление качеством в туризме. Москва, 2010. 304 с.

2. Квартальнов В.А. Менеджмент туризма. Москва : Финансы и статистика, 2009. 247 с.

3. Сидоренко I.O. Напрями щодо удосконалення системи управління якістю діяльності туристичних підприємств (організацій, фірм) в сучасних умовах господарювання. Формування ринкових відносин в Україні. Вип. 3 (46). 2005. С. 78-80.

4. Мальська М.П. Туристичний бізнес: теорія та практика. Київ, 2012. 368 с.

5. Устюгова Е.В., Попова Т.О. Туристский продукт и туристские услуги. ТДР. 2009. № 10. C. 59-60.

6. Index of economic freedom. URL: http://cf.heritage.org/index/pastScores.cfm (дата звернення: 05.12.2020).

\section{References:}

1. Baumgarten L.V. (2010) Upravlenie kachestvom v turizme [Quality management in tourism]. Moscow. (in Russian)

2. Kvartal'nov V.A. (2009) Menedzhment turizma [Tourism management]. Moscow: Finansy i statistika. (in Russian)

3. Sydorenko I.O. (2005) Napriamy shchodo udoskonalennia systemy upravlinnia yakistiu diialnosti turystychnykh pidpryiemstv (orhanizatsii, firm) v suchasnykh umovakh hospodariuvannia [Directions for improving the quality management system of tourism enterprises (organizations, firms) in modern business conditions]. Formuvannia rynkovykh vidnosyn v Ukraini, vol. 3 (46), pp. 78-80.

4. Malska M.P. (2012) Turystychnyi biznes: teoriia ta praktyka [Tourism business: theory and practice], Kyiv. (in Ukrainian)

5. Ustiuhova Ye.V. (2009) Turystychnyi produkt i turystychni posluhy [Tourist product and tourist services]. TDR, vol. 10, pp. 59-60.

6. Index of economic freedom. Available at: http://cf.heritage.org/index/pastScores.cfm (accessed 05 December 2020). 